University of Nebraska - Lincoln

DigitalCommons@University of Nebraska - Lincoln

Faculty Publications: Department of Entomology

2014

\title{
Grow them and we will come for the feast
}

\author{
Tiffany Heng-Moss \\ University of Nebraska-Lincoln, thengmoss2@unl.edu \\ Jeff Bradshaw \\ University of Nebraska-Lincoln, jbradshaw2@unl.edu \\ Kyle Koch \\ University of Nebraska-Lincoln, kkoch4@unl.edu \\ Travis Prochaska \\ University of Nebraska-Lincoln \\ Teresa Donze-Reiner \\ University of Nebraska-Lincoln, tdonze@wcupa.edu
}

See next page for additional authors

Follow this and additional works at: https://digitalcommons.unl.edu/entomologyfacpub

Part of the Entomology Commons

Heng-Moss, Tiffany; Bradshaw, Jeff; Koch, Kyle; Prochaska, Travis; Donze-Reiner, Teresa; and Sarath, Gautam, "Grow them and we will come for the feast" (2014). Faculty Publications: Department of Entomology. 365.

https://digitalcommons.unl.edu/entomologyfacpub/365

This Article is brought to you for free and open access by the Entomology, Department of at DigitalCommons@University of Nebraska - Lincoln. It has been accepted for inclusion in Faculty Publications: Department of Entomology by an authorized administrator of DigitalCommons@University of Nebraska - Lincoln. 


\section{Authors}

Tiffany Heng-Moss, Jeff Bradshaw, Kyle Koch, Travis Prochaska, Teresa Donze-Reiner, and Gautam Sarath 


\title{
Grow them and we will come for the feast
}

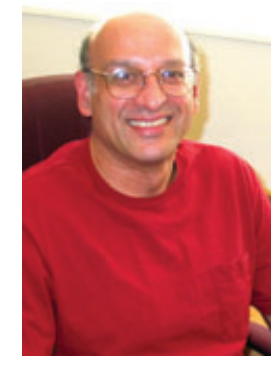

\author{
Tiffany Heng-Moss, Jeff Bradshaw, Kyle Koch, Travis Prochaska, \\ and Teresa Donze-Reiner, University of Nebraska at Lincoln, Lincoln, NE, USA \\ Gautam Sarath, Forage and Bioenergy Research Unit, USDA-ARS, Lincoln, NE, USA \\ Contact: Gautam.Sarath@ars.usda.gov
}

ustainable production of switchgrass and other bioenergy grasses will require effective pest management. Identification of potential insect pests and detailed characterization of the plant-insect interaction will better enable us to address emergent insect pests in production fields. An added uncertainty is how manipulation of plants for improved quality (e.g. lower lignin) will affect plant resistance to insect herbivory. Plants can utilize different mechanisms to defend against chewing versus piercing-sucking insects; however, some basal plant responses appear to be shared across diverse biotic stressors. The range and modulation of these responses are beginning to be addressed for several of the temperate, perennial, warm-season grasses that are designated as biomass crops. Other systems have demonstrated the need to become proactive in these studies. For instance, buffalograss, Buchloë dactyloides (Nuttall) Engelmann, was first introduced as a low-maintenance turf species. However, a number of important insect pests were documented within a relatively short time frame. ${ }^{1,2}$ Similarly, several recent reports have been published for switchgrass (Panicum virgatum L.) and Miscanthus (Miscanthus $x$ giganteus) that indicate the presence of insect pests in production fields, and the overall susceptibility of these species to insect herbivory. ${ }^{3-9}$

A number of aphid species can also feed on these perennial grasses. ${ }^{10} \mathrm{~A}$ more detailed evaluation of the suitability and categories of resistance present in tetraploid switchgrasses to feeding by two potential aphid pests have been conducted recently. ${ }^{11,12}$ Collectively, these studies demonstrate that the upland switchgrass cultivar, Summer, was generally susceptible to both the greenbug (Schizaphis graminum) and to the yellow sugarcane aphid (Sipha flava). The lowland switchgrass cultivar, Kanlow was highly resistant to both aphids, indicative of a strong antibiosis response. Interestingly, a population derived

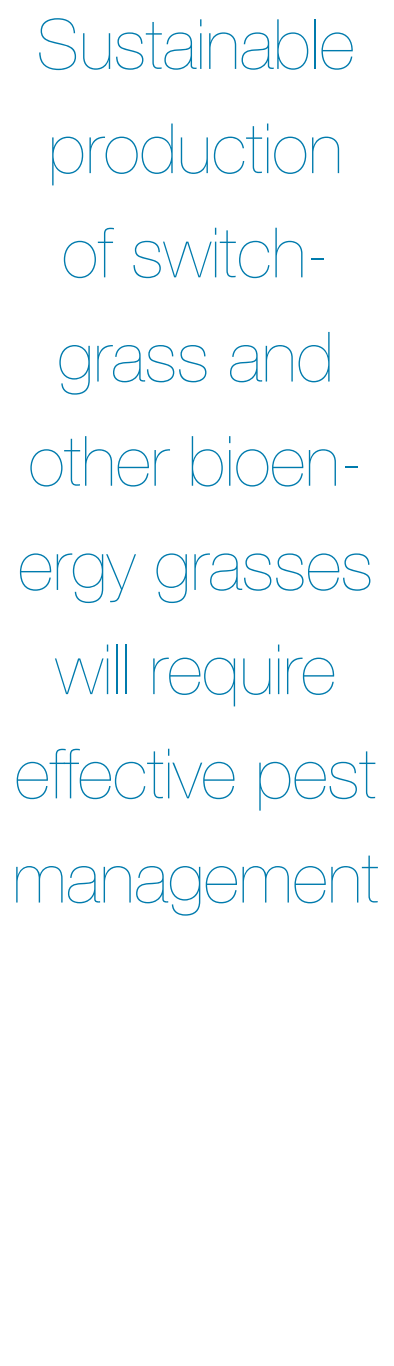


from crossing Kanlow x Summer plants exhibited tolerance to the yellow sugarcane aphid. These results demonstrate that multiple resistance mechanisms are present in switchgrasses and understanding these mechanisms could be important to the development of new germplasm with enhanced resistance to a broad array of insect pests. One of the most effective and sustainable strategies for controlling insect pests has been the development of insect-resistant plants. Studies cited here, and those in progress in many other research laboratories, should provide a foundation for development of sustainable pest management strategies that offer improved environmental safety and minimal human health risk.

\section{References}

1. Baxendale FP, Heng-Moss TM and Riordan TP, Blissus occiduus (Hemiptera : Lygaeidae): A chinch bug pest new to buffalograss turf. J Econ Entomol 92:1172-1176 (1999).

2. Heng-Moss TM, Baxendale FP, Riordan TP and Foster JE, Evaluation of buffalograss germplasm for resistance to Blissus occiduus (Hemiptera : Lygaeidae). J Econ Entomol 95:1054-1062 (2002).

3. Dowd PF and Johnson ET, Differential resistance of switchgrass Panicum virgatum L. lines to fall armyworms Spodoptera frugiperda (J. E. Smith). Genet Resour Crop Evol 56:1077-1089 (2009).

4. Dowd PF, Sarath G, Mitchell RB, Saathoff AJ and Vogel KP, Insect resistance of a full sib family of tetraploid switchgrass Panicum virgatum L. with varying lignin levels. Genet Resour Crop Evol 60:975-984 (2013).

5. Mitchell R, Vogel KP and Sarath G, Managing and enhancing switchgrass as a bioenergy feedstock. Biofuel Bioprod Bioref 2:530-539 (2008).

6. Nabity PD, Orpet R, Miresmailli S, Berenbaum MR and Delucia EH, Silica and nitrogen modulate physical defense against chewing insect herbivores in bioenergy crops miscanthus $\times$ giganteus and Panicum virgatum (Poaceae). J Econ Entomol 105:878-883 (2012).

7. Prasifka JR, Bradshaw JD, Boe AA, Lee D, Adamski D and Gray ME, Symptoms, Distribution and abundance of the stem-boring caterpillar, Blastobasis repartella (Dietz), in switchgrass. Bioenerg Res 3:238-242 (2010).

8. Prasifka JR, Bradshaw JD and Gray ME, Potential biomass reductions to Miscanthus $\mathrm{x}$ giganteus by stem-boring caterpillars. Environ Entomol 41:865-871 (2012).

9. Prasifka JR, Bradshaw JD, Meagher RL, Nagoshi RN, Steffey KL and Gray ME, Development and feeding of fall armyworm on Miscanihus $\times$ giganteus and switchgrass. J Econ Entomol 102:2154-2159 (2009).

10. Burd JD, Prasifka JR and Bradshaw JD, Establishment and host effects of cereal aphids on switchgrass (Panicum virgatum L.) cultivars. Southwest Entomol 37:115-122 (2012).

11. Koch KG, Fithian R, Heng-Moss TM, Bradshaw JD and Sarath G, Evaluation of tetraploid switchgrass populations (Panicum virgatum L.) for host suitability and differential resistance to four cereal aphids. $J$ Econ Entomol (in press).

12. Koch KG, Heng-Moss TM, Bradshaw JD and Sarath G, Categories of resistance to greenbug and yellow sugarcane aphid (Homoptera: Aphididae) in three tetraploid switchgrass populations. Bioenerg Res (in press).

Gautam Sarath

Forage and Bioenergy Research Unit, USDA-ARS, Lincoln, NE, USA

DOI: $10.1002 /$ bbb.1477 